\title{
White garment churches (Vapositori) and ZANU-PF party politics in Zimbabwe: True marriage or marriage of convenience during and post-Mugabe era
}

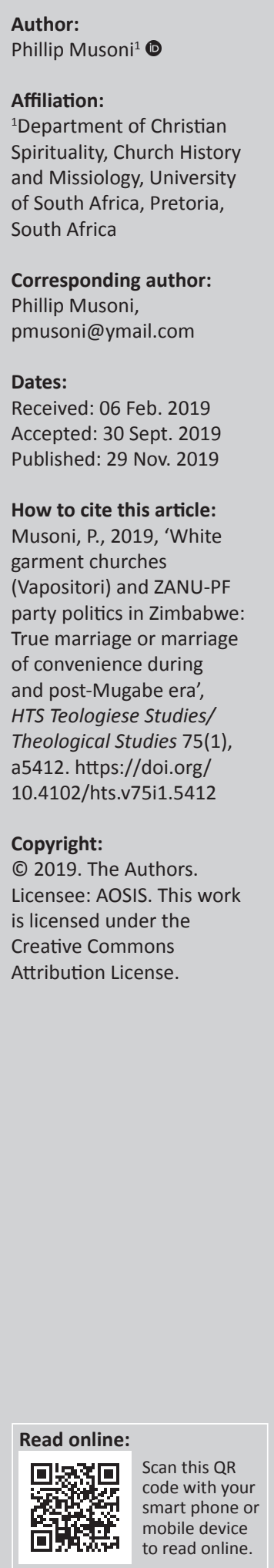

The white garment churches' (Vapositori) involvement in party politics, particularly in favour of ZANU-PF, continued to flourish in Zimbabwe even after the demise of Mugabe. Robert Gabriel Mugabe ruled Zimbabwe from 1980 until he was deposed by the Zimbabwean Army on 21 November 2017. Unlike other Christian boards in Zimbabwe, the Vapositori churches played a significant role in authenticating and validating the continuation of ZANU-PF holding onto power from 1980 till the present even after the removal of Mugabe. This article describes the relationship between ZANU-PF and Vapositori analogically as a marriage. This article posited that this marriage between Vapositori and the ruling ZANU-PF political party did not end with Mugabe. President Emmerson Dambudzo Mnangagwa and his vice president, Constantino Kuvheya Chiwenga, are seen masquerading Vapositori by attending and addressing Vapositori church gatherings. Thus, this article interrogates whether the marriage between Vapositori and ZANU-PF was borne out of real love or is just a marriage of convenience. Moreover, if it's a marriage of convenience then who controls whom and why? These and other related questions require a critical investigation to deepen our understanding of the 'Church and politics' in Zimbabwe during and after the Mugabe era.

Keywords: AICs; marriage; Mnangagwa; Mugabe; politics; ZANU-PF; Zimbabwe; white garment.

\section{Introduction}

The relationship between the white garment churches (Vapositori) and the ZANU-PF party continues to flourish in the Zimbabwean politics. The question is, can this relationship be equated to a 'true marriage' or typify a 'marriage of convenience?' The marriage of convenience as described in this article is a marriage entered into for motives 'other than that of a relationship, family, or love', but has 'been arranged for personal gain or some other sort of strategic purposes', such as politics (Messinger 2013:1).

Accordingly, this article compares the relationship prevailing between ZANU-PF and the Vapositori churches to a marriage. Studying the churches in Zimbabwe reveals that there are two broad categories, namely the so-called missionary churches and the African Indigenous Churches (AICs) (Chitando 2005:10). The first category is referred to as missionary churches because 'these churches were founded by white missionaries'. Examples of missionary churches in Zimbabwe today are the Anglican, the Roman Catholic and the Salvation Army, just to mention a few. The second category entails the AICs. These churches are referred to as African indigenous, independent, instituted, initiated churches because they were founded by Africans in Africa (Adogame 2013). The example of AICs in Zimbabwe are African pentecostal churches such as the Zimbabwe Assemblies of God Africa (ZAOGA) of Ezekiel Guti, the Zionists, such as the Zion Christian Church (ZCC) of Bishop Nehemiah Mutendi and the white garment churches (Vapositori) such as the Apostolic African Church (AAC) of Paul Mwazha, just to mention a few.

However, today, there is hardly a noticeable difference between these two strands of Christian churches in terms of church congregants and leaders in Zimbabwe because all their members and leaders are black Africans. One can barely see a white person in almost all these so-called missionary churches in Zimbabwe today. Perhaps, what makes these churches retain the label of 'missionary churches' even when almost all their members are black Africans is the fact that these churches continued to be guided spiritually by a theology adopted from the west (Muzorewa 1985). Accordingly, this could be the reason that some missionary churches, such as the Anglican Church and the Roman Catholic, continue to be known as the 'Church of England' and the 
'Church of Rome', respectively, even in a post-colonial Zimbabwe. With these two broad strands of Zimbabwean Christian churches today, for one to undertake an analysis of the relationship between white garment churches and the ZANU-PF party that has continued even after the removal of Mugabe, one must reflect and first analyse the relationship that existed between missionary churches and the colonial government before Zimbabwe gained independence in 1980 and the new role the missionary churches have played after 1980.

\section{Theoretical framework}

It is appropriate at this stage to look briefly at the theory which is at the core of this article. It is deliberately decided to equate the relationship between white garment churches and the ZANU-PF political party to a marriage.

This is a deliberate choice made because of a number of factors. Firstly, it is important to note the fact that marriage, as an institution, is always about power relations characterised by control and submission. Control and submission are characteristics of both Christian and African marriages, where a man in a marriage has been endowed with unquestionable executive powers to control the affairs of the home, while a woman must submit willingly to the authority of her husband for the sake of relationship. Again, whether Christian or African, marriage involves certain duties, entailing that if one partner acts, then the other partner will react to the action taken. Thus, relations between ZANU-PF and white garment churches are equated deliberately to a relationship which is entered into by two parties where one controls the affairs while the other follows and obeys willingly. Accordingly, this article seeks to argue that, although ZANU-PF and white garment churches are seen together, this does not necessarily mean that the marriage is flourishing. Therefore, the question raised throughout this article is who controls whom in this marriage and why. Using the same marriage relationship theory, this study notes that the Vapositori and ZANU-PF relations seem to replicate the relationship that existed between the colonial church and the British colonies in Rhodesia before Zimbabwe received its independence in 1980. For instance, the Anglican Church's peculiar position as the established Church of England, with its Bishop appointed by the British prime minister, bestowed on it a unique role with regard to providing a religious sanction for British colonies, while, on the other hand, the British administrators parcelled out land to this Church of England in Rhodesia (Lapsley 1988:115). According to Lapsley, no one thought it strange that the Anglican Church is situated next door to the Rhodesian parliament (Lapsley 1988:115).

Accordingly, with independence in 1980, a new era was ushered in the history of church and state relations in Zimbabwe. Firstly, the position of the Anglican Church as a kind of established church of the state since 1923 was terminated, ushering in a new dawn for AICs (Hallencreutz 1988:251).
This article observes that while the previous government had adopted a fairly restricted policy vis-à-vis these 'unrecognised' churches as many of these AICs were badly hit during the war, but with the introduction of new government such churches were recognised (Hallencreutz 1988:251). Perhaps the termination of the mutual relationship which missionary churches enjoyed during the British colonial regime in Rhodesia gave rise to the missionary church resuming a new office 'prophecy'/giving voice to the voiceless (Gundani 2008). Data were collected by means of both secondary and primary methods. The secondary sources consulted are relevant books on colonial and post-colonial church and state relations in Zimbabwe. The primary sources used for compiling data are the media accounts that include a myriad of newspaper and television reports on relations between white garment churches and ZANU-PF. Accordingly, the following section first discusses the colonial missionary church relationships with the British colonies and then the post-colonial missionary churches' relationship with ZANUPF. This ushers to the discussion of white garment churches and ZANU-PF: whether it is a true marriage or a marriage of convenience.

\section{Colonial and post-colonial missionary churches in Zimbabwean politics}

This article postulates that church and party politics in which ZANU-PF and the white garment churches in Zimbabwe are engaged is not a new phenomenon. Accordingly, this section points out that the colonial missionary church had a similar relationship with the colonial government of the day (Zhangazha 2017).

However, this relationship seems to have been weakened with the colonial government being replaced by the new government of Mugabe and his ZANU-PF party in 1980. The assumption that the colonial missionary church was extremely supportive of the colonial government of the day, is evidenced by the Church of England-Anglican securing prime land near and around the parliament house in Zimbabwe (Lapsley1988:115). To have a church building near and around the parliament house is an indication that the Church of England had an extremely good relationship with the government of the day. Not only did the colonial missionary churches benefit by being given land in the city centre, such as Anglican, Roman Catholic and Methodist all having church buildings right in the centre of Harare, the capital city of Zimbabwe, missionary churches also secured lands in rural areas and all these lands were given free of cost (Zhangazha 2017:11). This relationship continued up to 1980 till the change of government in Zimbabwe.

In 1980, the missionary church resumed a new office that gave voice to the voiceless (Gundani 2008). From 1982 onwards, we see the missionary church's prophetic role visible as masses went through violations during the Mugabe era.

The first human violation that took place after Zimbabwe's independence from the colonial regime was the result of 
Mugabe's ideology of a one-party state. The reason was that during the army struggle against the white colonial regime, the country had two main political parties, namely the PFZAPU of Joshua Nkomo and ZANU-PF of Robert Mugabe, among other small political parties. Accordingly, these two main political parties continued to be strong, while small parties such as ZIPRA and ZANLA grew weaker and weaker. In 1982, there were groups of bandits in Matabeleland, armed men robbing and damaging properties (Catholic Commission on Justice and Peace [CCJP] 1997). This article does not have time to explain the origin and motives of these bandits that roamed around in Matebeleland and killing mostly ordinary people. Accordingly, Mugabe and the ZANU-PF implicated PF-ZAPU in these killings, although PF-ZAPU denied this allegation. It is against this background that in the late January 1983, the 5th Brigade was deployed in Matabeleland North (CCJP 1997). Within weeks, they murdered more than 2000 civilians, beaten thousand more and destroyed hundreds of homesteads (CCJP 1997). This operation was known as Gukurahundi, which means the rain which washes away chaff before spring rains (CCJP 1997). We noted that Gukurahundi was not targeting only dissidents but also ordinary people, including women and children who were killed indiscriminantly. The 5 th Brigade was targeting anyone because it was instructed just to do so and kill everyone in sight. These killings took place mainly in Matabeleland because this is where PF-ZAPU had majority of its supporters, while ZANU-PF had majority of its supporters in Mashonaland.

Mugabe did not want any other political party except his ZANU-PF. It is against this background that from late 1985, ZANU-PF negotiated with ZAPU leaders to integrate ZAPU with ZANU-PF (CCJP 1997).

However, in reaction to these killings, the post-colonial missionary church was not silent. In 1983, Catholic bishops issued a statement entitled 'Reconciliation is still possible' (Gundani 2008). The CCJP, an organ representing missionary Christianity, issued a reconciliatory statement because hundreds and hundreds of innocent people who were neither dissidents nor collaborators of dissidents were dying every day (Gundani 2008). From that time onwards, we see that the post-colonial missionary church challenged Mugabe's campaign to extinguish other political parties and his drive for a one-party state. Thus, the Roman Catholic Church was at the forefront to condemn Mugabe for such actions. In retaliation, however, Mugabe described his opponents, namely, the CCJP as follows: 'Those who opposed the oneparty state are those people with little minds, those who misinterpret such a change as a threat to democracy' (Dombo 2014:137).

Thus, the ZANU-PF party perceived those accusing the ideology of one-party state as mercenaries of the west which promote the colonial regime change agenda (Dombo 2014). That's why Mugabe accused mainline churches of engaging in politics instead of attending to the spiritual needs of people (Dombo 2014).
Again, the role of missionary churches of being a watchdog came to the fore during the forced evictions of Zimbabweans in an operation called Murambatsvina (Sibanda \& Maposa 2013:133). The operation which started in May 2005 targeted the so-called illegal business premises housing flea markets, tuck shops and shabby-cum-backdoor shelters (Sibanda \& Maposa 2013:133) and affected all people regardless of their religious affiliations. Thus, the Vapositori congregants were also victims of operation Murambatsvina.

Besides destroying illegal houses and business structures, we noted that operation Murambatsvina also targeted churches whose congregants met in open spaces, namely the white garment churches (Sibanda \& Maposa 2013). Many of the white garment churches involved in informal business sectors and located in the backyard of light industries, where they made goods such as baskets, pushcarts, tinkered pots and chicken troughs (Sibanda \& Maposa 2013:133), were badly affected by Murambatsvina. These vocational activities were carried out with a religious fervour and commitment to the teachings of their founding fathers Johane Masowe and Johane Marange. Accordingly, many people were left homeless as many houses were destroyed because of the ZANU-PF's operation Murambatsvina.

Nevertheless, the above scenario contradicts the continuous support that ZANU-PF received from white garment churches during the Mugabe as well as post-Mugabe era. The question, therefore, is why do white garment churches continue to support a party that has cost some of their members' lives? Even after operation Murambatsvina, Mugabe was accommodated and allowed to address the Johane Marange Apostolic's annual Pascal conference held in July 2010 at Mafararikwa in Marange in the Manicaland Province (Sibanda \& Maposa 2013:134). In his address, Mugabe romanticised polygamy, a rampant practice among the Vapositori of Marange, giving examples of Biblical Solomon and David who had many wives. Accordingly, Mugabe's address showed how ZANU-PF in this marriage was involved in the battle of controlling the minds and souls of Vapositori by romanticising polygamous marriages. This romanticising of polygamous marriage was done in order to keep intact the marriage between Vapositori and ZANU-PF. Perhaps it is against this background that while other Christian organisations were active and extremely confrontational to ZANU-PF abusing people, the Union of the Development of Apostolic Churches in Zimbabwe Africa (UDACIZA), the Christian board that represents white garment churches, did not issue any statement against the violations perpetrated by ZANU-PF supporters, perhaps because their organisation was afraid of being victimised by the ruling party.

\section{White garment church groupings in Zimbabwe}

The white garment churches are mainly divided into two categories, namely those whose theology and spirituality is drawn from the Bible, and the other group which do not read 
the Bible but claim to hear from the Holy Spirit, live and direct (Engelke 2007). The Johane Marange Apostolic Church and the African Apostolic Church (yekwa Mwazha; AAC) read and use the Bible, but all the Johane Masowe churches do not read or use the Bible in their church services (Bishau 2010). Although these churches are divided into two main categories, what links them is their theology of the land: Africa belongs to Africans (Sibanda \& Maposa 2013:131). Thus, these church groupings, in essence, shared the same theology of the land, a theology that subscribes to the belief that God, in his creation, divided the land and allocated people to different continents, hence Africa was primarily allocated to black Africans (Sibanda \& Maposa 2013:125). The other common factor among the two main groupings is the understanding that white missionary churches came to displace the African cultures and traditions (Mukonyora 2007).

Some of the cultures and traditions displaced by white missionary churches are polygamous (barika) and child marriages (kuzvarira). Although some do not marry more than one wife, most of the Vapositori have many wives. Perhaps it is for this reason that Vapositori churches have more members than any other church in Zimbabwe (Sibanda \& Maposa 2013:130). It is also central among these two church groupings that girls are not allowed to marry outside the church. However, a boy can marry outside the church, although some punishment is meted out for few months, thereafter the punishment ceases. Accordingly, a boy is permitted to marry outside the church because this results in more members in the church. Another common feature among these Vapositori groupings is that both groupings currently discourage their church members from accessing bio-medical health delivery systems or engaging in the immunisation of their children (Vengeyi 2011). These Vapositori groupings emphasise the centrality of the work of the spirit through their church leaders. Church leader's sayings are binding and become doctrine of the church. It is also important to note that these churches do not use or congregate in church buildings. They use open spaces for church services even in harsh weather conditions. Accordingly, even in the diaspora, the white garment churches do not use buildings for church services. Instead, they congregate in open spaces (Dodo 2014). Then with this in mind, one can ask why the ZANU-PF leaders deliberately fail to address such issues during their visits to Vapositori gatherings?

\section{ZANU-PF and the white garment church relations during Mugabe era}

The history of ZANU-PF and Vapositori could be traced back to the time of Mugabe, when he was the president of Zimbabwe. The union of ZANU-PF and Vapositori came into prominence in 1980, when a prophecy made by Madzibaba Wimbo in 1957 allegedly came true (Manhanga 2016). Madzibaba Wimbo (Majinesta) had predicted to the colonial government that the independent Rhodesia would be led by a man with the name of the angel Gabriel. In 1980, Robert Mugabe, whose middle name is Gabriel, was elected to office.
From that time, although he was a devout Catholic Church member, Mugabe was seen on several occasions in white garment churches, wearing white garments and masquerading as one of them. Accordingly, this study posits that ZANU-PF deliberately turned a deaf ear to the issues such as child marriages and not sending children to school and discouraging their church members from accessing biomedical health delivery systems (Machingura 2014:185). Accordingly, we found that this deliberate turning a blind eye to such martyring beliefs and practices (Machingura 2014:175) by ZANU-PF during their addresses at Vapositori services was only aimed at making their marriage work. This marriage is important for ZANU-PF because the party needed Vapositori votes. That's why on 05 November 2017 in the Rufaro Stadium (Guri 2017:1), Mugabe invited and addressed all white garment churches and other groups of Zionist Church. The purpose of this gathering was to manipulate people to lobby support so that Mugabe could continue as Zimbabwe's president even though he was 93 years old. This Sunday of 05 November 2017 was like the last supper for Mugabe and the Vapositori, because that was the last day on which Mugabe and Grace addressed Vapositori before his impeachment that led to his resignation as the leader of ZANU-PF on 21 November 2018 (Guri 2017:1). Accordingly, this participation of Vapositori in party politics is viewed by critics as problematic and even scary in the Zimbabwean context (Guri 2017). For Guri, Super Sunday of 05 November 2017, as it was designated, which took place in the Rufaro Stadium, was a clear indication of 'church capture', taking place in Zimbabwean Christianity. Guri (2017:3) used the term 'church capture' because for him 'it is similar and analogous to "state capture," a type of systemic political corruption in which private interests significantly influence a state's decision-making processes to its own advantage'. Just as much as the decision-making 'processes of a state can be sabotaged, usurped and overtaken by private interests, so can the integrity of the Church', be compromised as was the case by ZANU-PF in Zimbabwe during the Mugabe era (Guri 2017:3). Thus, Guri (2017:3) further argues that Super Sunday of 5 November 2017 in Harare signifies 'church capture', for all purposes and intents 'an intentional diversion and subvention of the lifeblood and energy of the Church, towards a personal, selfish, egoistic', self-aggrandising, selfserving agenda. Accordingly, this article discusses the marriage existing between ZANU-PF and white garment churches that seem to have polarised the universal church figuratively from its main purpose to speak on behalf of the voiceless (Guri 2017). It is interesting to note in this study as to what type of marriage exists between Vapositori and ZANU-PF which continues even after the Mugabe regime.

\section{The white garment churches and ZANU-PF in the post-Mugabe era}

It is interesting to note that the marriage between Vapositori and ZANU-PF did not end even after the overthrow of Mugabe by the army, with Emmerson Dambudzo Mnangagwa subsequently taking over as president. In 2015, the escalation of succession debate became apparent as 
evidenced by the then vice president Emmerson Mnangagwa visiting the Mt Darwin Wimbo Shrine (Kwaramba \& Mugove 2015). The authors pointed out that besides Mnangagwa going there to officiate at a school, which was built in the memory of the Johanne Masowe Chishanu Vadzidzi leader, Madzibaba Wimbo, he inquired about who would succeed Mugabe and when. As alluded earlier too by Kwaramba and Mugove (2015), Wimbo is the one who predicated the ascension of Mugabe into power. In the same way, Wimbo could predict Mugabe's descent from power for Mnangagwa. According to My Zimbabwe News of 6 February 2019, Madzibaba Wimbo confirmed publicly Mnangagwa as Mugabe's successor during that visit (Mugabe 2019).

Perhaps this is the reason why even after the Mugabe era, ZANU-PF cadres continued to visit Vapositori churches. Constantino Guveya Dominic Nyikadzino Chiwenga, Zimbabwe's vice president, also engaged in the custom of visiting white garment churches to gather their support for harmonised elections. In some of his addresses, vice president Chiwenga posited that 'no one is credited for coining the name ZANU-PF, but the name ZANU-PF came straight from God in heaven' (ZBC Live Broadcasting-Mashonaland Central, 7 July 2018). The grand claim that the name 'ZANU

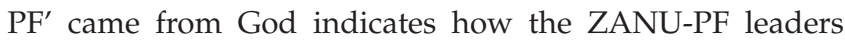
manufactured and legitimatised the long stay of ZANU-PF in power ahead of other political parties in Zimbabwe. 'This declaration was also supported by the Vapositori predictions' that Mnangagwa was going to win the 30 July 2018 harmonised elections, thereby keeping ZANU-PF in power (Nyangani 2018). According to Chiwanga (2018) this prediction 'was announced at the Mafararikwa Shrine in Bocha, Marange, where more than 250000 members of the church gathered for the annual Passover Feast':

President Mnangagwa was invited by the church's leader, Mutumwa Noah Taguta, to attend the 17-day event that ends on Tuesday. Thousands of congregants from several African countries also turned up for the Passover event. More than six evangelists who ministered during a church service held before the Passover said Mnangagwa would romp to victory with ease. (p. 3)

It is important to note that after this prophecy, Mnangagwa responded by ensuring the freedom of worship for Vapositori churches during his leadership as the elected president of Zimbabwe. In a way, this assurance strengthened the ZANUPF and Vapositori marriage.

Similar to what had been the case for Robert and Grace Mugabe, president Mnangagwa and his wife, Auxilia Mnangagwa, are seen masquerading as Vapositori church members for support from the most popular church groupings in Zimbabwe, the Johane Marange and the Johane Masowe Church, respectively.

On 25 June 2018, Auxilia Mnangagwa, the first lady, attended a Johanne Masowe Church service in High fields where she sat on the ground, barefooted, sang and listened attentively the sermons alongside other church members
(Chikwati 2018:25). The majority of ordinary believers seemed to have regarded the first lady's visit as an honour for their church. In her remarks, she started by attesting that the Johane Masowe Chishanu Church was her home. In her speech, she attested that she grew up in the Johane Masowe Chishanu Church (Chikwati 2018). To authenticate her claims, she further alluded to the fact that she used to pray with Madzibaba Gibson. It was interesting to hear that Auxillia became a Johane Masowe member during the days of Madzibaba Gibson, one of the old disciples of Johane Masowe. The first lady alluded to the fact that she only left the Masowe Church when she got married to join the church her husband was attending (Chikwati 2018). Thus, her remarks that day opened the door for her to be accepted in the Johane Masowe Church. Although her visit was primarily to campaign against cancer, she used shrewdly the opportunity to campaign for ZANU-PF.

This study has traced the long historical linkage between ZANU-PF and Vapositori in Zimbabwe. This linkage or relationship has been described as a marriage. However, the question remains, as what type of marriage is this? Is the Church willing to invite ZANU-PF leaders, or is the Church afraid of ZANU-PF? Are they strange bedfellows or partners in good faith? Thus, the last section of this study discusses what brings these two entities together.

\section{Vapositori and ZANU-PF in a marriage}

Although this study has shown that ZANU-PF did not spare Vapositori's illegal accommodation and business shelters during operation Murambatsvina, contrastingly Vapositori seem to continue supporting ZANU-PF. Thus the question is why Vapositori continued to support ZANU-PF even after their houses and business structures were destroyed by ZANU-PF under restoration orders. Is the support for ZANU-PF a result of these churches' love for the party, or are these churches doing this for other reasons? There are several postulations that could be formulated regarding Vapositori supporting ZANU-PF during the Mugabe and post-Mugabe eras. Perhaps the first reason why Vapositori seems to continue supporting ZANU-PF is their doctrine of open space congregation. From the research yet to be published, the author of this article has gathered that open space worship has typified the religious identity of Vapositori in both Zimbabwe and outside its borders. Thus, it is observed in these researches that if one travels around any city or village of Zimbabwe, one cannot fail to notice the rate at which the white garment churches have infiltrated nearly all open spaces in health hazardous manner. Over the weekends, every piece of open space is turned into a sacred shrine for Vapositori. However, the author of this article has highlighted earlier in this article that this practice of congregating in open spaces is in spotlight because this has been condemned by city fathers, town planners and government authorities guided by health policies and by-laws (Kadirire 2017). The condemnation became serious in 2015 when various Vapositori churches took over many of the city's open spaces 
in contravention of the city by-laws (Lubinda 2015). For instance, the Harare News stated that the majority of their church sites fall short of the required standards because they fail to provide water and proper ablution facilities (Lubinda 2015). That's why Vapositori invites ZANU-PF leaders to address them during their gatherings in open spaces to authenticate their occupation of such spaces. It is noted in this study that during the ZANU-PF addresses at Vapositori gatherings, Mugabe and Mnangagwa never condemned open space gatherings, child marriages and the churches' custom of not sending girls to school, as these matters are left to be addressed by Vapositori. Instead, ZANU-PF leaders would promise freedom of worship and freedom of assembly if the Vapositori members vote for their party.

The second reason for the existence of Vapositori and ZANUPF marriage is Vapositori's occupation of lands acquired via unofficial channels (Nyangani 2018). Although the Johane Masowe churches do not have long-term land allocated to them, the Johane Marange and the AAC of Paul Mwazha have designated lands. These two Vapositori churches have central shrines for big events. For example, the Johane Marange Church groupings converge annually at the Mafararikwa Shrine in Bocha in the Mutare province, while the AAC of Mwazha converges at Guvambwa in Chihota, Sadza village, in the Mashonaland East province (Nyangani 2018). Arguably, for these two Vapositori groupings, the accusation of causing health hazards does not apply because these two churches have structures for ablution. Perhaps the reason why these two churches constantly invite ZANU-PF leaders during such big functions is that the lands they occupy were grabbed from the rightful owners and that these churches have been allocated farms unconstitutionally by the present ruling party - ZANU-PF (Nyangani 2018). In other words, these big farmlands occupied by churches are the reasons for them to continue their support for the ruling party. During the colonial regime, no AIC could own land for church activities (Sundkler 1991). In addition, on introspection one discovers that the ZANU-PF strongholds during the Mugabe era were Manicaland, Mashonaland Central and Masvingo provinces, among other provinces, and mostly rural areas. The Vapositori churches and ZCC were given farms either for the church or just for the founder of the church. Thus, Bishop Mutendi was given vast tracts of land in Masvingo, stretching from Chiredzi to Gokwe. We have Mbungo as the ZCC shrine and Defe in Gokwe as the second biggest ZCC shrine (Chimininge 2014). Furthermore, in Manicaland, the Johane Marange Church was allocated large pieces of land, as was the case with Paul Mwazha of AAC, who was given vast pieces of land in Chihota, Sadza village in Mashonaland East. All these were incentives used by ZANU-PF to gather support during the elections.

The third factor that has substantiated this marriage is the fact that both Vapositori churches and ZANU-PF existed during the colonial government. It is important to note that the Johane Masowe and Johane Marange Church groupings emerged in the 1930s during the white colonial regime. The AICs experienced the ruthlessness of the colonial government.
Since the emergence of AICs was closely connected with African nationalists, colonial administrators could not see the difference between AICs and nationalist groupings advocating regime change (Chitando 2005). In addition, prophetic utterances on the integrity of blacks in these churches coincided with the nationalist cry that 'Africa belongs to Africans' (Vengeyi 2011). That's why all these Vapositori churches do not convert into whites churches, even Vapositori in the diaspora (Musoni 2019:56). Thus, the hatred that Mugabe and his ZANU PF and Vapositori had for whites is the same. Perhaps this hatred for whites, a common factor between ZANU-PF and Vapositori, has sustained their marriage despite all challenges. Hence, most AICs consider their church leaders and political leaders as God ordained to deliver them from colonial and cultural imperialism. Thus, Robert Mugabe and Ezekiel Guti were seen as angels sent by God to free Zimbabweans from western ideologies (Biri 2013:112).

\section{Conclusion}

This article discussed the marriage between Vapositori and the ZANU-PF during and after the Mugabe era. We found that although the two were seen together, the Vapositori churches were manipulated by the ruling party for selfish political ends just like pawns in a game of chess. We noted that the political leaders' wearing white garments and masquerading as Vapositori members continue to be a common practice and tool that ZANU-PF uses to amass political support even after the demise of Robert Mugabe.

Accordingly, the marriage between Vapositori and ZANU-PF can be described allegorically as a marriage for political expediency, rather than for love and family unity. Political leaders' attending the Vapositori gatherings has not been in good faith, but rather lobbying for political support during elections. Thus, from the Mugabe era to this day, ZANU-PF has captured the minds and souls of Vapositori by taking advantage of the Vapositori theology on messianic leaders. Most of these Vapositori understand that their church leader was sent by God to deliver black Africans from white domination and imperialism.

Consequently, it is concluded that the life blood of these Vapositori congregants lies in their leaders. The Vapositori members do what their leader commands. Hence, capturing a leader means capturing the members; that's what ZANUPF has been doing to remain in political power.

Thus, if the leader says, 'let's support the ruling party', all the members would follow him or her faithfully.

Therefore, this article postulates that the marriage between Vapositori and ZANU-PF is a marriage of convenience and has been entered into for political and religious gains. We noted that ZANU-PF is in control in this marriage, while Vapositori is the subject that would always dance to ZANU $\mathrm{PF}$ tune. This thus resulted in all Vapositori converging in the Rufaro Stadium on 05 November 2015 for Mugabe's address. 


\section{Acknowledgements Competing interests}

The author has declared that no competing interests exist.

\section{Author(s) contributions}

The author declares that he is the sole author of this research article.

\section{Ethical consideration}

This article followed all ethical standards for a research without direct contact with human or animal subjects.

\section{Funding information}

This research received no specific grant from any funding agency in the public, commercial or not-for- profit sectors.

\section{Data availability statement}

Data sharing is not applicable to this article as no new data were created or analysed in this study.

\section{Disclaimer}

The views and opinions expressed in this article are those of the author and do not necessarily reflect the official policy or position of any affiliated agency of the author.

\section{References}

Adogame, A., 2013, The African Christian diaspora: New currents and emerging trends in World Christianity, Bloomsbury, New York.

Biri, K., 2013, 'African pentecostalism and politics in post-colonial Zimbabwe: A comparative critique of the leadership styles of Ezekiel Guti and Robert Mugabe', in E. Chitando (ed.), Prayers \& players: Religion and politics in Zimbabwe pp. 111-124, Southern Africa Printing and Publishing House (SAPES), Harare.

Bishau, D., 2010, Reign with him for thousand years (Rev 20:6): A socio-hermeneutical expositition of biblical and contemporary millenarian movements in Zimbabwe as radical responses to deprivation, 2 nd edn., J. Kugler, L. Togarasei \& M. Gunda (eds.), University of Bamberg Press, Bamberg.

CCJP and LRF, 1997, Breaking the Silence, Building the Peace: A Report on the Disturbances in Matabeleland and the Midlands, 1980-1988, CCJP and LRF.

Chikwati, E., 2018, 'First lady intensifies cancer awareness campaigns', Herald Newspaper, 25 June, p. 25.

Chimininge, V., 2014, 'Zion Christian church: A case study', in E. Chitando, R. Gunda \& J. Kugler (eds.), Multiplying in the spirit: African initiated churches in Zimbabwe, pp. 33-48, University of Bamberg Press, Bamberg.

Chitando, E., 2005, 'Naming the phenomena: The challenge of African independent churches', Studia Historiae Ecclesiasticae XX1(1), 85-110.

Chiwanga, S., 2018, 'LIVE: President Mnangagwa at Johane Marange Shrine', Zimbabwe Daily News, 14 July, viewed 01 January 2018, from https://www.thezimbabwedaily. $\mathrm{com} /$ news/241587-live-president-mnangagwa-at-johane-marange-shrine.html.
Dodo, O., 2014, 'African initiated churches, pivotal in peace-building a case of the Johane Masowe Chishanu', Journal of Religion and Society - The Kripke Center, viewed 03 September 2016, from moses.creighton.edu/jrs/2014/20149.pdf.

Dombo, S., 2014, 'Refusing to be co-opted? Church organizations and reconciliation in Zimbabwe with special reference to the Christian Alliance of Zimbabwe 2005-2013', Journal for the Study of Religion 27(2), 137-171.

Engelke, M., 2007, A problem of presence: Beyond scripture in an African church, University of California Press, Berkeley, CA.

Gundani, P., 2008, 'Prophecy, politics and power: Changing relations between theCatholic church and the Zimbabwean state (1980-2007)', Studia Historiae Ecclesiasticae 53(9), 1689-1699. https://doi.org/10.1017/СВ09781107415 324.004

Guri, W., 2017, 'ZANU-PF captures the Church', 6 November 2017, viewed 30 Apri 2018, from https://www.thezimbabwean.co/2017/11/zanu-pf-captures-church/

Hallencreutz, C., 1988, 'Ecumenical challenge in independent Zimbabwe: ZCC 1980-1985', in C. Hallencreutz \& A. Moyo (eds.), Church and state in Zimbabwe, pp. 251-311, Mambo Press, Gweru.

Kadirire, H., 2017, 'Vapostori resist ban on open-air worship', Nehanda Radio, Daily News, viewed 26 September 2017, from https://nehandaradio.com/2017/09/26/ vapostori-resist-ban-open-air-worship/

Kwaramba, F. \& Mugove, K., 2015, 'Mnangagwa in bizzarre apostolic rites', Daily News, 06 October, viewed 11 August 2018, from https://www.dailynews.co.zw/ articles/2015/10/06/mnangagwa-in-bizarre-apostolic-rites.

Lapsley, M., 1988, 'Anglican church and state from UDI in 1965 until independence of Zimbabwe 1980', in C. Hallencreutz \& A. Moyo (eds.), Church and state in Zimbabwe, pp. 115-126, Mambo Press, Gweru.

Lubinda, L., 2015, 'Debate over Mapositori use of open space', Harare News, p. 4, viewed 16 June 2015, from https://doi.org/10.1063/1.351465

Machingura, F., 2014, 'Martyring of people over radical beliefs: A critical look at the Johane Marange Apostolic church's perception of education and health (family planning methods)', in E. Chitando, M.R. Gunda \& J. Kugler (eds.), Multiplying in the spirit: African initiated churches in Zimbabwe, pp. 175-198, University of Bamberg Press, Bamberg.

Manhanga, M., 2016, 'Mudzidzi Wimbo: Untold story', Online publication, viewed 10 September 2018, from http://www.sundaymail.co.zw/mudzidzi-wimbo-untoldSeptem
story/.

Messinger, I., 2013, There is Something about marrying... the case of human rights vs. migration regimes using the example of Austria, Journal of Laws, p. 1090, Department for Political Sciences, Alumna University of Vienna, Vienna.

Mugabe, T, 2019, 'ED Mnangagwa's rise to power was prophesied by the late Mudzidzi Wimbo', My Zimbabwe News, 14 February, viewed 04 April 2019, from https://www.myzimbabwe.co.zw/news/40740-ed-mnangagwas-rise-to-powerwas-prophesied-by-the-late-mudzidzi-wimbo.html\%0A\%0A.

Mukonyora, I., 2007, Wandering a gendered wilderness: Suffering \& healing in an African initiated church, P. Lang, New York.

Musoni, P., 2019, 'African indigenous churches for black Africans: A study of the Johani Masowe Chishanu ye Nyenyedzi (JMCN) missiological thrust in the diaspora', Studia Historiae Ecclesiasticae 45(2), 16. https://doi.org/10.25159/2412$4265 / 4493$

Muzorewa, G., 1985, The origins and the development of African theology, Orbis Books, New York.

Nyangani, K., 2018, 'ED will win elections: Vapostori', viewed 25 July 2018, from https://www.newsday.co.zw/2018/05/ed-will-win-elections-vapostori/.

Sibanda, F. \& Maposa, R., 2013, 'Behind the smokescreen: African instituted churches and political processes in Zimbabwe', in Ezra Chitando (ed.), Prayers \& players: Religion and politics in Zimbabwe, pp. 125-142, SAPES, Harare.

Sundkler, B., 1991, 'African independent churches and their political roles', in C. Hallencreutz \& M. Palmberg (eds.), Religion and politics in Southern Africa, pp. 85-89, The Scandinavian Institute of African Studies, Uppsala.

Vengeyi, O., 2011, 'Mapositori churches and politics in Zimbabwe: Political dramas to win the support of Mapositori churches', Exchange 40(4), 351-368. https://doi. org/10.1163/157254311X600753

Zhangazha, T., 2017, 'Church, faith and politics in Zimbabwe: Recalling the secular', viewed 26 July 2018 , from www.o4z.org.zw/index.php/news/politics/900-churchfaith-and-politics-in-zimbabwe-recalling-the-secular- $2 \% 0 \mathrm{D}$. 